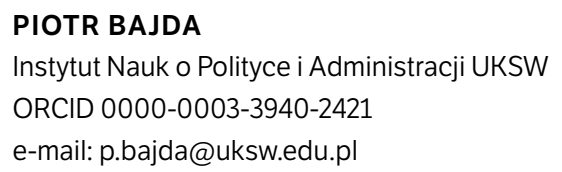

\title{
Stanowisko Czech i Słowacji wobec Inicjatywy Trójmorza -
} od inaugurującego szczytu w Dubrowniku po spotkanie w Lublanie

\section{The Position of the Czech Republic and Slovakia towards the Three Seas Initiative:}

From the Inaugural Summit in Dubrovnik to the Latest One in Ljubljana

Słowa kluczowe:

Inicjatywa Trójmorza,

Republika Czeska, Republika Słowacka, małe państwa
Keywords:

Three Seas Initiative, Czech Republic, Slovak Republic, small states 
The Position of the Czech Republic and Slovakia towards the Three Seas Initiative: From the Inaugural Summit in Dubrovnik to the Latest One in Ljubljana

This article attempts to identify the decision-making process of the authorities in the Czech Republic and Slovakia accompanying the establishment of the Three Seas Initiative - a new project of regional cooperation in Central Europe. Describing the reactions of Prague and Bratislava to the presidential summit in Dubrovnik inaugurating the project and the subsequent evolution of the attitudes of both countries in recent years makes it possible to show the role and importance attributed to the Three Seas Initiative by the Czechs and Slovaks. 


\section{Czechy, Słowacja, Inicjatywa Trójmorza, małe państwa}

zesi i Słowacy od początku powstania Inicjatywy Trójmorza (TSI) podchodzili do tego nowego formatu współpracy regionalnej z dużym dystansem. Warto nadmienić, że prezydent Republiki Czeskiej Miloš Zeman pierwszy raz osobiście uczestniczył w szczycie TSI w słoweńskiej Lublanie w 2019 r.; wcześniej wyręczał go w tym minister transportu lub przewodniczący (marszałek) Izby Poselskiej. Słowacy demonstracyjnie do Dubrownika na pierwsze spotkanie inaugurujące projekt wysłali Petera Pellegriniego, ówczesnego wicepremiera w rządzie Roberta Ficy. Ta chłodna reakcja na polsko-chorwacki projekt była wynikiem splotu wielu czynników, których identyfikacja posłużyła do przygotowania tego artykułu. Polityka środkowoeuropejska Pragi i Bratysławy w kontekście Inicjatywy Trójmorza, jej dążenia deklarowane, postrzegane i realizowane zostaną tak przeanalizowane, by można było wskazać główne okoliczności towarzyszące podejmowanym decyzjom przez rządzących w Czechach i na Słowacji ${ }^{1}$.

\section{Charakterystyka funkcjonowania małych państw na arenie międzynarodowej}

Kategoria małych państw nie została w pełni skodyfikowana w nauce o stosunkach międzynarodowych, choć istnieje jako odrębna kategoria badawcza. W literaturze przedmiotu do tej grupy zalicza się państwa, które w szczególności charakteryzują się niewielkim terytorium i małą liczbą mieszkańców, co przy ograniczonych możliwościach rozwoju gospodarczego i zdolnościach obronnych skutkuje często traktowaniem takich krajów w kategorii słabych aktorów stosunków międzynarodowych ${ }^{2}$. Powszechnym ich doświadczeniem jest borykanie się z brakiem siły politycznej, gospodarczej, wojskowej,

1 Takie właśnie ujęcie metodologiczne w analizie Inicjatywy Trójmorza, z perspektywy aktorów uczestniczących w projekcie, zaproponowano w pracy: A. Orzelska-Strączek, P. Ukielski, Inicjatywa Trójmorza z perspektywy jej uczestników, Instytut Studiów Politycznych PAN, Warszawa 2020.

2 Próby zbudowania definicji małego państwa były podejmowane przede wszystkim przez różne agendy ONZ, instytucje finansowe czy też $w$ ramach jednego z sympozjów noblowskich (corocznych konferencji organizowanych pod auspicjami Komitetu Noblowskiego); zob.: P. Bajda, Małe państwo europejskie na arenie międzynarodowej. Polityka zagraniczna Republiki Słowackiej w latach 1992-2016, 
a nawet wizerunkowej. Oczywiście w każdej z tych kategorii możemy znaleźć wyjątki (np. siła militarna Izraela, potęga gospodarcza Kataru), lecz w tych przypadkach mamy raczej bardziej do czynienia $\mathrm{z}$ potwierdzeniem reguły niż z obaleniem tezy. Te obiektywne deficyty powodują, że małe państwa muszą przyjmować specyficzne strategie przetrwania na arenie międzynarodowej, zaznaczające ich podmiotowość czy stale podkreślające prawo do autonomicznych działań i decyzji.

Powszechnym dążeniem małych państw jest podkreślanie zasadniczej roli prawa międzynarodowego jako regulatora wzajemnych stosunków. Prawo międzynarodowe mniej lub bardziej doskonale chroni słabszych aktorów (chociażby za pomocą instrumentu sankcyjnego) przed zastosowaniem siły przez agresywnych uczestników stosunków międzynarodowych. Prawo to od strony formalnej zakłada równość wszystkich aktorów międzynarodowych, czyli niweluje jedną ze słabości, i promuje wizję stosunków międzynarodowych opartych na współpracy w miejsce realistycznej walki o wpływy. To wszystko stanowi o atrakcyjności liberalnego podejścia do stosunków międzynarodowych, które preferują państwa małe. Inną ze strategii, często wykorzystywanych przez małe i słabe stolice, jest angażowanie się $\mathrm{w}$ regionalne sojusze o charakterze politycznym i obronnym, szczególnie tam, gdzie tego rodzaju współpraca jest dobrze rozwinięta. Stąd powszechne dążenie małych państw europejskich do integracji z Unią Europejską, często połączone z zabiegami na rzecz członkostwa w Sojuszu Północnoatlantyckim, co ma gwarantować kolektywną obronę bez względu na rzeczywistą siłę obronną napadniętego ${ }^{3}$.

Ważną cechą konstruującą definicję małego państwa jest także - poza mierzalnymi wskaźnikami, takimi jak terytorium i liczba obywateli deklarowana przez ich przywódców chęć odgrywania tej specyficznej roli na arenie międzynarodowej. Tu dotykamy zasadniczego tematu rozważań, gdyż autodefiniowanie się w kategoriach małego aktora międzynarodowego jest cechą wpisaną w tradycje polityczne Czech i Słowacji, co zostało zapoczątkowane decyzjami pierwszego prezydenta Czechosłowacji Tomasza Garrigue'a Masaryka. Międzywojenne porównanie Czechosłowacji i Węgier ukazuje, jak ważnym elementem w relacjach międzynarodowych staje się

Ośrodek Myśli Politycznej i Wydawnictwo Naukowe Uniwersytetu Kardynała Stefana Wyszyńskiego w Warszawie, Kraków-Warszawa 2018, s. 31-43.

3 Szerzej o strategiach funkcjonowania małych państw na arenie międzynarodowej zob.: tamże, s. 43-46. 
deklarowana rola. Masaryk z założenia definiował Czechosłowację w kategoriach małego aktora, kraju który miał być państwem inteligentnym, a niekoniecznie silnym ${ }^{4}$. Podczas gdy mniejsze od ówczesnej Czechosłowacji terytorialnie i ludnościowo Węgry, niepogodzone ze swoją pozycją międzynarodową po podpisaniu traktatu w Trianon (1920), kwestionowały przypisaną im rolę małego państwa i aktywnie dążyły do rewizji postanowień traktatowych. Interesujące, że reminiscencje tych historycznych debat możemy odnaleźć także dzisiaj, a ich wpływ jest widocznym atrybutem cechującym współczesną politykę zagraniczną Pragi czy Budapesztu i deklarowanych ról na arenie międzynarodowej.

\section{Znaczenie współpracy regionalnej w polityce zagranicznej Czech i Słowacji}

Aktywność na poziomie regionalnym jest jednym z głównych wyznaczników funkcjonowania małych państw na arenie międzynarodowej i ważnym składnikiem strategii $\mathrm{w}$ ich polityce zagranicznej, ważniejszym niż w przypadku państw średnich czy dużych. Ta działalność nie jest wyłącznie podyktowana chęcią odgrywania aktywnej roli w relacjach $\mathrm{z}$ najbliższymi sąsiadami, ale realistyczną strategią wzmacniania swojej pozycji na arenie międzynarodowej, zwłaszcza wobec regionalnych potęg i w różnych formatach współpracy multilateralnej. Dlatego tak dużą wagę Czechy lub Słowacja przywiązują do swoich działań, np. w formacie Grupy Wyszehradzkiej, który jest dla nich głównym narzędziem budowania pozycji w regionie, ale też szerzej - szczególnie wykorzystywanym na poziomie europejskim. Warto zauważyć, że na oficjalnych witrynach internetowych czeskiego i słowackiego ministerstwa spraw zagranicznych współpraca wyszehradzka jest opisywana w oddzielnych sekcjach pośród innych głównych celów polityki zagranicznej ${ }^{5}$.

4 Koncepcję tę najszerzej zaprezentował T. G. Masaryk, Kroměřiž lectures. Problem of a small nation, Nakladatelství TRIGON, Praha 2010, s. 11.

5 Grupa Wyszehradzka na stronie słowackiej wymieniona jest na szóstym miejscu (po ONZ, NATO, OBWE, Radzie Europy i OECD), dostępny w internecie [dostęp: 12 VI 2020]: <https://www.mzv.sk/zahranicna_politika/slovensko_a_v4-vysehradska_skupina>, podczas gdy na czeskiej (w trochę innym układzie) zajmuje miejsce drugie, po czesko-niemieckim strategicznym dialogu, dostępny w internecie [dostęp: 12 VI 2020]: <https://www.mzv.cz/jnp/cz/zahranicni_vztahy/cr_v_evrope/ visegrad/index.html $>$. 
Dla porównania - na stronie polskiego MSz dużo trzeba się naszukać, by w części „co robimy” odnaleźć lakoniczną informację o v4, i tylko dzięki przejęciu przez Polskę przewodnictwa w Grupie Wyszehradzkiej trochę więcej informacji pojawia się w sekcji „aktualności”, co uświadamia nam, jakie znaczenie przypisywane jest do tego formatu współpracy w polityce zagranicznej poszczególnych stolic ${ }^{6}$.

Nie oznacza to, że Grupa Wyszehradzka jest wartością bezwzględną dla mniejszych państw V4. Odgrywa konkretną pomocniczą rolę w ich strategiach. Jeśli z powodów niezależnych, np. od Pragi czy Bratysławy, nie realizuje tych zadań, to oba państwa gotowe są do inicjowania innych formatów współpracy regionalnej. $\mathrm{W}$ tych kategoriach należy rozumieć utworzony w 2015 r. tzw. Trójkąt Sławkowski, nieformalne ugrupowanie regionalne Austrii, Czech i Słowacji powołane w związku z osłabieniem współpracy wyszehradzkiej i próbą budowania alternatywnego sojuszu opartego na współpracy trzech rządów socjaldemokratycznych ${ }^{7}$. Jednak z chwilą, gdy aktywność pod szyldem v4 zaczęła przynosić więcej korzyści (np. w sprawie narzucanego przez Komisję Europejską kwotowego podziału uchodźców), wówczas w czasie słowackiej prezydencji w Grupie Wyszehradzkiej (lipiec 2015 - czerwiec 2016) ten format stał się podstawą współpracy i sposobem na osiągnięcie oczekiwanych celów politycznych.

Grupa Wyszehradzka, przy wszystkich swoich ograniczeniach, przynosi najwięcej wartości dodanej małym państwom, przede wszystkim Pradze i Bratysławie. Już sama jej konstrukcja jest dość specyficzna. Mimo licznych deklaracji dotyczących chęci przystąpienia do v4 (Litwa, Rumunia, nieoficjalnie Słowenia czy Austria), decyzją głównie małych państw, w zależności od niedoszłego kandydata, czy to na wniosek Węgier albo Czech, do żadnego rozszerzenia formatu wyszehradzkiego nie doszło. Dla polskich partnerów z V4 ekskluzywne członkostwo w regionalnej koalicji przynosi dużo pożytku politycznego, przede wszystkim wzmacnia i pozytywnie wyróżnia na arenie międzynarodowej Czechy, Słowację i Węgry na tle

6 Zob:: informacje [dostęp: 3 VI 2020], dostępny w internecie: <https:/www.gov.pl/web/ dyplomacja/grupa-wyszehradzka >; 〈https://www.gov.pl/web/dyplomacja/aktualnosci〉.

7 Szerzej: J. Groszkowski, Deklaracja sławkowska. Nowy format wspótpracy regionalnej, Ośrodek Studiów Wschodnich [online], 4 II 2015 [dostęp: 13 VI 2020], dostępny w internecie: 〈https://www.osw.waw.pl/pl/publikacje/analizy/2015-02-04/ deklaracja-slawkowska-nowy-format-wspolpracy-regionalnej $>$. 
innych małych państw europejskich. Grupa Wyszehradzka stanowi bowiem wygodny lewar polityczny dla mniejszych państw, wzmacniający ich pozycję oraz pozwalający na zbudowanie marki i rozpoznawalności; stanowi też duży atut $\mathrm{w}$ kontaktach międzynarodowych, szczególnie w relacjach z państwami odległymi geograficznie od Europy Środkowej. Trudno byłoby znaleźć uzasadnienie dla częstych kontaktów np. Słowacji z Japonią czy Indonezją, ale już o wiele łatwiej jest namówić rządzących w Tokio do bilateralnych rozmów $\mathrm{z}$ Bratysławą $\mathrm{w}$ trakcie spotkania w szerszym regionalnym formacie v4 plus ${ }^{8}$.

Taka postawa partnerów wyszehradzkich, czyli brak zgody na rozszerzenie formatu V4, i jednoczesne pragmatyczne jego wykorzystanie w celu wzmocnienia swojej pozycji politycznej, jest zgodna z założeniami teorii minilateralizmu, której zarysy w 2009 r. przedstawił Moisés Naím na łamach „Foreign Policy”. Według jego badań, szczególnie w przypadku funkcjonowania państw na forach multilateralnych, dla osiągnięcia celów partykularnych, potrafią łączyć się w najmniejszą z możliwych liczbę stolic gwarantującą im największą siłę ${ }^{9}$. Jeśli zatem na v4 spojrzymy jako na sposób politycznego wzmocnienia pozycji wybranych państw najpierw $\mathrm{w}$ ich polityce integracyjnej ${ }^{10}$, a obecnie na forum unijnym i w relacjach z odległymi geograficznie stolicami, wówczas można zrozumieć przywiązanie Czech, Słowacji czy Węgier do tego formatu. Elitarne członkostwo w dobrze rozpoznawanym ugrupowaniu regionalnym jest bardziej

8 Na przykład szczyt v4 + Japonia kończył polską prezydencję w 2013 r.; parę miesięcy później podczas węgierskiego przewodnictwa odbyło się kolejne spotkanie $\mathrm{w}$ tym formacie, zakończone podpisaniem porozumienia o współpracy państw wyszehradzkich z Japonią w obszarze badań naukowych i współpracy technologicznej, by podczas słowackiego przewodnictwa w 2019 r. zorganizować kolejny szczyt V4 z udziałem japońskiego premiera.

9 M. Naím, Minilateralism. The magic number to get real international action, „Foreign policy" [online], 21 VI 2006 [dostęp: 16 VI 2020], dostępny w internecie: <https:// foreignpolicy.com/2009/06/21/minilateralism/>.

10 Czego dobrą ilustracją może być wsparcie udzielone Słowacji przez pozostałe państwa wyszehradzkie w jej staraniach o nadrobienie straconego czasu w negocjacjach akcesyjnych z UE i NATO po odsunięciu premiera Vladimíra Mečiara od władzy w 1998 r.; szerzej: K. Żarna, Od Mečiara do Dzurindy. Główne kierunki polityki zagranicznej Republiki Stowackiej w latach 1993-2002, Wydawnictwo Uniwersytetu Rzeszowskiego, Rzeszów 2015, s. 148-158. 
wartościowe od powiększania V4 o nowych kandydatów, z którymi wypadałoby dzielić się prestiżem ${ }^{11}$.

Ten sam mechanizm możemy obserwować w przypadku wspomnianego już nowego formatu współpracy - Trójkąta Sławkowskiego, z którego pozytywnymi rezultatami jego założyciele wiązali więcej nadziei, niż jest to jego dotychczasowym dorobkiem. Nie oznacza to, że należy uznać projekt Trójkąta Sławkowskiego za zamknięty, raczej szczególnie w przypadku Czech i Słowacji stanowi on swoistą alternatywę dla V4 - inny sposób wzmacniania swojej pozycji na arenie europejskiej. Często w Pradze czy Bratysławie, w czasie dyskusji o współpracy w regionie środkowoeuropejskim, słyszymy, że dla nich stanowi to paralelę wobec formatu Trójkąta Weimarskiego. Skoro więc Polska ma prawo do autonomicznych form współpracy z wybranymi partnerami, czego przykładem jest Trójkąt Weimarski, to analogicznie Czesi i Słowacy są uprawnieni do korzystania $\mathrm{z}$ tego samego mechanizmu zgodnego $\mathrm{z}$ ich interesem narodowym. $\mathrm{Z}$ punktu widzenia interesów politycznych Warszawy to nie w budowaniu nowych formuł należy dostrzegać niebezpieczeństwo. Ważniejsze jest identyfikowanie i ewentualne przeciwdziałanie próbom rozgrywania obu formatów przeciw sobie, czego ilustracją była niedawna postawa prezydenta Francji Emmanuela Macrona, który podkreślał znaczenie Trójkąta Sławkowskiego jako ważnego elementu konstruującego Europę, pomijając przy tym jakąkolwiek rolę Grupy Wyszehradzkiej ${ }^{12}$. Może pojawiać się zatem w Pradze czy Bratysławie pokusa, by w sytuacji ostrego konfliktu na forum europejskim (na tle spraw dotyczących praworządności lub wokół wieloletnich ram finansowych) wykorzystać ten swoisty polityczny by-pass, żeby osiągnąć własne, partykularne cele negocjacyjne. To nie zmienia jednak strategii, że Grupa Wyszehradzka jest stale instrumentem pierwszego

11 Szerzej: P. Bajda, Współpraca wyszehradzka - nowe wyzwania w zmieniającej się Europie. Ocena polskiej prezydencji w V4 2012/13. Od minilateralizmu do makroregionu, [w:] Europa Środkowa - Central Europe, t. 3: Instytucje demokracji bezpośredniej, zaǵadnienia systemów politycznych $i$ współpracy regionalnej w Europie Środkowej, red. K. Koźbiał, Państwowa Wyższa Szkoła Zawodowa im. Rotmistrza Pileckiego w Oświęcimiu, Oświęcim 2015, s. 192-194.

12 Za: BM, MNIE, Węgierska prasa: Macron gra na rozbicie jedności Grupy Wyszehradzkiej, TVP.info [online], 9 VI 2018 [dostęp: 22 VI 2020], dostępny w internecie: <https://www.tvp.info/38011927/wegierska-prasa-macron-gra-na-rozbicie-jednosci-grupy-wyszehradzkiej $>$. 
wyboru w polityce regionalnej polskich partnerów uczestniczących w tym formacie współpracy.

Dotychczasowe doświadczenia z nowymi projektami regionalnymi przekładają się jednak na recepcję Inicjatywy Trójmorza, której utworzenie oficjalnie zostało ogłoszone pod koniec sierpnia 2016 r. na szczycie założycielskim w Dubrowniku. Pomysł prezydenta RP Andrzeja Dudy i prezydent Chorwacji Kolindy Grabar-Kitarović okazał się ofertą średnio atrakcyjną dla małych państw, które aktywnie funkcjonują w innych formatach współpracy regionalnej. Najbardziej wstrzemięźliwą reakcję można było usłyszeć w stolicach Czech i Słowacji.

\section{Inicjatywa Trójmorza bardziej wyzwaniem niż szansą dla Pragi i Bratysławy}

Polsko-chorwacki projekt w Pradze i Bratysławie został w pierwszym momencie przyjęty ze swoistym zaskoczeniem i daleko idącą rezerwą, a dowodem na to jest m.in. niska ranga członków delegacji wysłanych do Dubrownika (zob. tabela 1). W momencie inauguracji formatu trójmorskiego Czesi i Słowacy nie dostrzegali w tym projekcie jakiejś wartości dodanej, wręcz przeciwnie - odczytali to bardziej jako próbę naruszenia status quo i ich pozycji w regionie oraz deprecjację Grupy Wyszehradzkiej. Wydaje się, że swoistym wyrazicielem poglądów w tamtych dniach był Vít Dostál, dyrektor praskiego centrum badawczego Asociace pro mezinárodní otázky (АМо), które jest niezależnym think tankiem, ale bardzo często współpracującym z czeskim resortem dyplomacji. W czerwcu 2016 r. AMO opublikowało analizę autorstwa Dostála, którą dodatkowo syǵnowano projektem New Horizons of Czech-Polish Cooperatioon w ramach Forum Polsko-Czeskiego ${ }^{13}$. Już sam tytuł: Understanding New Polish Intermarium: Trap Or Triumph for the Visegard Group? wskazywał na tezę próbującą przeciwstawić V4 projektowanej Inicjatywie Trójmorza. Autor analizy uznał, że Grupa Wyszehradzka zawsze miała drugorzędne znaczenie w polskiej polityce zagranicznej, wyrażał także obawy, iż nowy format będzie sposobem

13 Jak jest podane na stronie MSZ, Forum Polsko-Czeskie powstałe w 2008 r. regularnie organizuje konkursy dotacyjne, których celem jest przełamywanie wzajemnych stereotypów i nawiązywanie współpracy na różnych płaszczyznach; szerzej: gov.pl [online], dostępny w internecie [dostęp: 22 VI 2020]: <https://www.gov.pl/ web/dyplomacja/forum-polsko-czeskie>. 
na wciągnięcie całej Europy Środkowej do instrumentarium wzmacniającego pozycję polską na arenie międzynarodowej kosztem opóźnienia integracji europejskiej. Przedstawiając natomiast projektowane nowe forum współpracy środkowoeuropejskiej, wskazywał, jak często w szerszym gronie z partnerami regionalnymi spotykali się przywódcy i ministrowie państw Grupy Wyszehradzkiej w formacie $\mathrm{V}{ }^{14}{ }^{14}$, obejmując tą współpracą wszystkie stolice, których przywódcy zostali zaproszeni na szczyt dubrownicki. W innej części przytaczanej analizy dobitnie zostały powiedziane dwie rzeczy, że nowa koncepcja współpracy regionalnej zaalarmowała wielu decydentów w Pradze i Bratysławie, którzy nie są zainteresowani wchodzeniem w żadną koalicję przeciwko kanclerz RFN Angeli Merkel, a także nie dostrzegali w polskiej propozycji żadnej wartości dodanej dla siebie ${ }^{15}$.

Czeska i słowacka odpowiedź na pierwsze zaproszenie do Chorwacji musiała być dla organizatorów szczytu lekkim rozczarowaniem, ale jednocześnie wymusiła ponowne przeanalizowanie całej koncepcji, gdyż dostrzeżono, że Praga i Bratysława uznały za niespójne cele deklarowane, postrzegane i realizowane w momencie inauguracji Inicjatywy Trójmorza. Z jednej strony organizatorzy deklarowali chęć wykorzystania nowego formatu do wzmocnienia całej Unii Europejskiej i ograniczyli krąg zaproszonych do udziału na pełnych prawach do członków UE, lecz do Dubrownika nie przyjechał nikt z ważniejszych przedstawicieli Komisji Europejskiej; byli za to obecni wiceministrowie spraw zagranicznych Chin (Liu Haixing) i Turcji (Ahmet Yildiz) ${ }^{16}$. Jak wskazał jeden ze słowackich ekspertów Tomáš Strážay, dyrektor think tanku SFPA - Słowacja i inne małe państwa

14 V4+ jest luźnym formatem pozwalającym na dopraszanie wybranych partnerów na konkretne wydarzenia organizowane pod szyldem Grupy Wyszehradzkiej; stanowi swoisty substytut w zamian za decyzję o nieprzyjmowaniu nowych członków do wyszehradzkiego klubu; zob.: P. Bajda, The Visegrad Group in the security architecture of Europe, „The Warsaw Institute Review” 2018, vol. 4, issue 7, s. 10-17 [online], dostępny w internecie [dostęp: 24 VI 2020]: <https://warsawinstitute. review/category/issue-2018/issue-42018/>.

15 V. Dostál, Understanding New Polish Intermarium: Trap or Triumph for the Visegrad Group?, „Policy Paper” 2016, vol. 3, s. 2-8 [online], dostępny w internecie [dostęp: 24 VI 2020]: <http://www.amo.cz/wp-content/uploads/2016/o6/amocz_PP_03_2016_ web.pdf $>$.

16 Szerzej: P. Kowal, A. Orzelska-Stączek, Inicjatywa Trójmorza: geneza, cele i funkcjonowanie, Instytut Studiów Politycznych PAN, Warszawa 2019, s. 56-60. 
oczekują od tej formy współpracy przede wszystkim korzyści gospodarczych, a format prezydenckich spotkań w sposób jednoznaczny wskazywał na ich charakter polityczny ${ }^{17}$. W czeskich i słowackich komentarzach wyraźnie zatem można było odczuć niezwerbalizowaną obawę, że Warszawa chce wciągnąć do współpracy politycznej swoich partnerów, z której to Polska ma uzyskiwać największą wartość dodaną, lecz kosztem dotychczasowych formatów kooperacji, jak Grupa Wyszehradzka. Te lęki dodatkowo potęgowano w Pradze i Bratysławie historycznym doświadczeniem polskiej koncepcji międzymorza z okresu międzywojennego. Słowacy dodatkowo obawiali się utraty swojego elitarnego miejsca $w$ regionie, jedynego członka unii walutowej wśród państw Grupy Wyszehradzkiej, a jednocześnie eksperta mającego ogromny wpływ na modelowanie współpracy V4 z państwami Bałkanów Zachodnich. Bratysławie zależało na zachowaniu status quo, ograniczającego współpracę w regionie do formatu $\mathrm{V} 4^{+}$, co gwarantowało im współuczestnictwo i kontrolę nad procesem decyzyjnym, gdyż decyzję w Grupie Wyszehradzkiej podejmuje się na zasadach konsensu.

Chłodną reakcję niektórych stolic na Inicjatywę Trójmorza należy jeszcze rozważyć w kontekście specyficznego funkcjonowania małych państw na arenie międzynarodowej. Jeśli bowiem państwa te nie widzą wyraźnego własnego interesu oraz nie dostrzegają w nowych formach współpracy wartości dodanej, to takie oferty będą one traktowały jako niepotrzebne, dodatkowe obciążenie dla swoich ograniczonych zasobów administracyjnych. Z perspektywy państw dużych czy średnich braki zasobów ludzkich w administracji nie wydają się tak znacznym problemem, ale np. w Estonii do praktyki należy to, że część ambasadorów tego państwa nie rezyduje na stałe w kraju urzędowania, ale pracuje w centrali, w Tallinie ${ }^{18}$.

Dopiero nowy czynnik w postaci bardzo silnego wsparcia udzielonego Inicjatywie Trójmorza przez prezydenta USA Donalda Trumpa, który stał się głównym gościem drugiego szczytu TSI w Warszawie w lipcu 2017 r., wymusił na Pradze i Bratysławie weryfikację ich dotychczasowych stanowisk. Autoryzacja dla projektu udzielona przez Waszyngton stała się bodźcem zmieniającym dotychczasowe reguły gry. Nowa postawa Czechów i Słowaków była zgodna z ich dotychczasową polityką i wynikami badań

17 Tamże, s. 77.

18 Zob.: P. Bajda, Małe państwo..., s. 69. 
nad zachowaniami małych państw na arenie międzynarodowej, które dość jednoznacznie wskazują, że tak jak w relacjach ze średnimi aktorami i pretendującymi regionalnymi liderami mniejsze podmioty mogą sobie pozwolić na chłodny stosunek do nowych projektów, tak również przy uzyskaniu autoryzacji ze strony silnych ośrodków politycznych sprzeciw zostaje zamieniony na bardziej otwartą postawę. Głównym celem takiej wyczekującej postawy jest weryfikacja, czy zainteresowanie wielkiego mocarstwa projektem Inicjatywy Trójmorza ma charakter stały, czy to tylko rezultat taktycznych posunięć obliczonych na uzyskanie doraźnych korzyści. W przypadku potwierdzenia stałego zainteresowania mocarstwa daną problematyką mali aktorzy będą próbowali pokazać swoją gotowość do odgrywania roli pomocniczej ${ }^{19}$. Szczególnie że wizyta prezydenta USA w Warszawie, poza ważnym wymiarem politycznym, przyniosła konkretną propozycję gospodarczą - ofertę zaopatrywania regionu w surowce energetyczne $^{20}$. Tej oceny nie zmienia absencja prezydenta Republiki Czeskiej Miloša Zemana na warszawskim szczycie TSI, skoro okazała się przede wszystkim rezultatem osobistego rozczarowania czeskiego przywódcy brakiem zaproszenia na bilateralne spotkanie z Donaldem Trumpem, o co usilnie zabiegał od 2016 r. $^{21}$ Bardziej charakterystyczny dla dynamiki rozwoju projektu Inicjatywy Trójmorza stał się swoisty wyścig o prawo organizowania trzeciego szczytu TSI w 2018 r. Było to testem o tyle ważnym, że przed warszawskim spotkaniem i wizytą Trumpa w środowisku ekspertów oraz komentatorów wyrażano obawy, iż po dwóch wydarzeniach organizowanych przez inicjatorów projektu (Chorwację i Polskę) może zabraknąć trzeciego, gotowego do podjęcia się roli gospodarza. Według relacji osób uczestniczących $\mathrm{w}$ szczycie warszawskim (przedstawionych

19 Charakterystyczną strategią funkcjonowania małych państw na arenie międzynarodowej jest poszukiwanie swoistej niszy tematycznej, w której taka stolica mogłaby się specjalizować, a także, co nie mniej ważne, być aktorem pomocnym dla silniejszych graczy, rozwiązującym niemalże w ich zastępstwie jakieś problemy. Tym należy sobie np. tłumaczyć zaangażowanie Słowacji w problematykę Bałkanów Zachodnich; zob.: P. Bajda, Małe państwo..., s. 260-263.

P. Kowal, A. Orzelska-Stączek, Inicjatywa Trójmorza..., s. 66.

21 J. Haszczyński, Milos Zeman - Donald Trump. Czeski film z niewdzięcznym prezydentem USA, "Rzeczpospolita” [online], 27 VII 2017 [dostęp: 25 VI 2020], dostępny w internecie: <https://www.rp.pl/Swiat/307249892-Milos-Zeman---Donald-TrumpCzeski-film-z-niewdziecznym-prezydentem-USA.html $>$. 
w nieformalnych dyskusjach), prezydent Rumunii Klaus Iohannis zaprosił na kolejne spotkanie do Bukaresztu, jeszcze zanim padło pytanie o gotowość jego organizacji.. Należy jednak zaznaczyć, że warszawskie spotkanie tylko częściowo wypełniło cel deklarowany w postaci unijnego wymiaru inicjatywy; co prawda spotkanie zgromadziło o wiele szersze grono prezydenckie, reprezentujące środkowoeuropejskie państwa członkowskie UE, ale ciągle nie zmobilizowało do obecności przedstawicieli Komisji Europejskiej.

Dopiero spotkanie zorganizowane przez prezydenta Rumunii Klausa Iohannisa, które miało miejsce w Bukareszcie we wrześniu 2018 r., odbyło się przy udziale przewodniczącego Komisji Europejskiej Jean-Claude'a Junckera, a nawet ministra spraw zagranicznych RFN Heiko Maasa. Szczególnie istotne okazały się zabiegi o udział w szczycie tego drugiego gościa, co było rezultatem zmiany postawy rządu niemieckiego wobec tej nowej formuły współpracy regionalnej. Niemcy, po udziale prezydenta Donalda Trumpa $\mathrm{w}$ warszawskim szczycie, przestali lekceważyć nowy projekt, dostrzegając w TSI mechanizm, który może na trwałe wpisać się w architekturę Unii Europejskiej. Berlin nie mógł sobie pozwolić na stanie z boku, dyplomacja niemiecka zaczęła więc aktywnie zabiegać $\mathrm{w}$ trakcie bukareszteńskiego spotkania nawet o status pełnoprawnego uczestnika projektu dla RFN. Nie spotkało się to jednak z pozytywną odpowiedzią ze strony wszystkich delegacji i zakończyło przyznaniem RFN roli państwa partnerskiego (jaki mają Stany Zjednoczone, a także Komisja Europejska, czy też Europejski Bank Odbudowy i Rozwoju) ${ }^{22}$. Dodatkowym czynnikiem uaktywniającym politykę Berlina stała się zapowiedź powołania do życia mechanizmu finansującego projekty infrastrukturalne w regionie, czyli Funduszu Trójmorza. Niebezpieczeństwo pozostania na marginesie tych decyzji było dla Berlina zbyt wysokie, stąd ich bardziej aktywna postawa. W Bukareszcie z Inicjatywą Trójmorza pogodziła się także Komisja Europejska, o czym dobitnie świadczyły słowa przewodniczącego Komisji Europejskiej Jean-Claude'a Junckera, który podczas szczytu namawiał, by projekt stał się formą:

otwierania nowych korytarzy łączących [...] części Europy, nie tylko Południe i Północ, ale także Wschód i Zachód, abyśmy mogli [...] rozwijać,

22 Ł. Janulewicz, T. Żornaczuk, Niemcy wobec Inicjatywy Trójmorza, „Biuletyn Polski Instytut Spraw Międzynarodowych" 2019, nr 120 (1868), s. 1-2. 
osiągnąć, ukończyć projekt przemawiający do wszystkich Europejczyków niezależnie od tego, gdzie żyją ${ }^{23}$.

Ważnym rezultatem szczytu bukareszteńskiego było nie tylko uzyskanie akceptacji dla tego projektu ze strony Komisji Europejskiej czy Niemiec jako najsilniejszego wspólnotowego aktora, ale także uzgodnienie listy konkretnych projektów w obszarze infrastruktury transportowej, energetycznej i teleinformatycznej. Na podstawie zgłoszeń przedstawianych przez poszczególne państwa powstał spis 27 projektów wielostronnych i 21 bilateralnych ${ }^{24}$. Opracowanie priorytetowych inwestycji okazało się dla Czechów i Słowaków spełnieniem postulatu, aby Inicjatywa Trójmorza miała charakter praktycznego instrumentu wspierającego współpracę gospodarczą. Należy podkreślić, że Bratysława i Praga na listę projektów wpisały inwestycje strategiczne, które w ostatnich latach nie mogły uzyskać wystraczającego wsparcia ze strony funduszy europejskich. Słowacy zaproponowali zatem projekt budowy gazociągu, który ma zapewnić rolę państwa tranzytowego i połączyć ich z Węgrami, Rumunią i Bułgarią (projekt łącznika z Polską jest dopisany jako zadanie do zgłoszonej przez Warszawę inwestycji Baltic Pipe $)^{25}$. Republice Czeskiej zależy na realizacji wielkiego projektu zbudowania drogi wodnej Dunaj-Łaba-Odra, który umożliwiłby odnowienie rzecznego transportu ładunkowego na tych szlakach ${ }^{26}$. Obok własnych inicjatyw Czesi i Słowacy zadeklarowali udział w kilkunastu pozostałych projektach, m.in. Via Carpatia czy szlak drogowy E65 (E66), by tylko wspomnieć największe przedsięwzięcia. Wyrazem pragmatycznego podejścia Praği i Bratysławy stała się deklaracja w sprawie uczestniczenia w projekcie

23 Apel szefa KE na szczycie Trójmorza o współpracę Wschodu i Zachodu, "GazetaPrawna.pl" [online], 18 IX 2018 [dostęp: 29 VI 2020], dostępny w internecie: <https://biznes.gazetaprawna.pl/artykuly/1264268,apeluje-o-wspolprace-wschodu-izachodu-na-szczycie-trojmorza.html >.

24 Lista została zamieszczona na oficjalnej stronie internetowej towarzyszącej bukareszteńskiemu szczytowi, dostępny w internecie [dostęp: 29 VI 2020]: < http:://three-seas.eu/wp-content/uploads/2018/o9/LIST-OF-PRIORITY-INTERCONNECTIONPROJECTS-2018.pdf>.

25 Mowa o projekcie „Eastring”, dostępny w internecie [dostęp: 29 VI 2020]: <https:// www.eastring.eu/page.php?page=about $>$.

26 Czesi uruchomili stronę projektu, który ma przybliżać idee żeglugi rzecznej na tych trasach, dostępny w internecie [dostęp: 29 VI 2020]: 〈http://www.d-o-l.cz/index.php/pl〉. 
Funduszu Trójmorza, w którym udział nie jest obowiązkowy. Podczas bukareszteńskiego szczytu sześć z dwunastu państw wyraziło zainteresowanie nowym pomysłem (Polska, Czechy, Słowacja, Rumunia, Chorwacja i Łotwa $)^{27}$. Uruchomienie samego funduszu wymagało jeszcze wielu zabiegów, a głównymi inicjatorami prac był polski Bank Gospodarstwa Krajowego i rumuński Exim Bank, które zdecydowały się na jego zarejestrowanie w Luksemburgu, co zostało zakomunikowane 5 czerwca 2019 r. podczas ostatniego z zorganizowanych szczytów Inicjatywy Trójmorza w Lublanie. Mimo wstępnej deklaracji zainteresowania ani Czesi, ani Słowacy nie podjęli kolejnych decyzji dotyczących przystępowania do funduszu w postaci zadeklarowania oraz wpłacenia swoich wkładów; finansowo w projekt są obecnie zaangażowane Polska, Rumunia i ostatnio - Estonia ${ }^{28}$.

\section{Podsumowanie}

Próbując zrozumieć postawę Republiki Czeskiej i Słowacji wobec zainicjowanej w sierpniu 2016 r. Inicjatywy Trójmorza, warto zauważyć, że ten nowy projekt współpracy w regionie środkowoeuropejskim, podobnie jak Grupa Wyszehradzka, był oryginalnym i autonomicznym (czyim?) pomysłem. W przeciwieństwie jednak do v4 w tym formacie ani Praga, ani Bratysława nie zostały doproszone do ośrodka decyzyjnego, który ograniczał się do Polski i Chorwacji - nie miały więc takiego jak w formacie wyszehradzkim wpływu na jego kształt. $\mathrm{Na}$ wstępnym etapie konstruowania idei $\mathrm{w}$ obu stolicach odczuwano swoisty dysonans między formalnie deklarowaną rolą a rzeczywistymi działaniami towarzyszącymi pierwszym decyzjom, odnoszącym się chociażby do formatu prezydenckiego przy jednoczesnym skupieniu się na problematyce infrastrukturalnej. Dodatkowo obawy, że Inicjatywie Trójmorza zostanie przypisana rola kolejnego instrumentu osłabiania integracji europejskiej (co groziło

27 Fundusz Inwestycyjny Inicjatywy Trójmorza - czym jest nowa inicjatywa BGK?, „300Gospodarka" [online], 1 VIII 2019 [dostęp: 29 VI 2020], dostępny w internecie: <https://3oogospodarka.pl/explainer/fundusz-inwestycyjny-inicjatywy-trojmorzaczym-jest-nowa-inicjatywa-bgk-explainer $>$.

28 O początkowym stadium tworzenia Funduszu Trójmorza może świadczyć dość skromna zawartość oficjalnej strony internetowej, dostępne w internecie [dostęp: 29 VI 2020]: 〈https://3siif.eu/〉. 
pogorszeniem relacji z głównym partnerem gospodarczym, Niemcami), powodowało, iż Bratysława i Praga początkowo podchodziły do polsko-chorwackiej propozycji z dużą rezerwą.

Aktywne włączenie się do gry o wpływy w regionie, głównie gospodarcze, przez amerykańskiego prezydenta Donalda Trumpa spowodowało konieczność weryfikacji przez Pragę i Bratysławę dotychczasowej strategii chłodnego dystansu do Inicjatywy Trójmorza. Perspektywa dostępu do dodatkowego wolumenu surowców energetycznych, możliwość nawiązania relacji biznesowych z Ameryką zmusiła obie stolice do zadeklarowania swojego zainteresowania projektem. Do pełnej akceptacji brakowało pozytywnego syǵnału płynącego od dwóch najważniejszych aktorów europejskich Komisji Europejskiej i Republiki Federalnej Niemiec, co nastąpiło rok później na szczycie w Bukareszcie. Dodatkowym argumentem, przemawiającym za aktywnym włączeniem się w proces konstruowania TSI, było powołanie do życia Funduszu Trójmorza, który stworzył szanse na zdobycie dodatkowych środków na ważne projekty infrastrukturalne, niedofinansowywane dotychczas w odpowiedniej skali przez programy europejskie.

Wszystkie te okoliczności tworzą odpowiednie warunki do aktywnego włączenia się Pragi i Bratysławy w nowy format współpracy środkowoeuropejskiej, ale nie będzie to oznaczać absolutnego poparcia dla wszelkiego rodzaju działań podejmowanych w przyszłości. Czesi i Słowacy będą każdą z propozycji dokładnie kalkulować. Jeśli uznają, że dalsze zaangażowanie może przynosić im więcej szkody niż zysku, to z wycofaniem się nie będą mieli problemu. W dużym stopniu zależy to też od działań polskiej dyplomacji, której kroki są bacznie obserwowane w obu stolicach. Czynnikiem mogącym podtrzymać pozytywny stosunek Pragi i Bratysławy do Inicjatywy Trójmorza będzie unikanie sytuacji deprecjonujących rolę Grupy Wyszehradzkiej. Polska prezydencja $\mathrm{w}$ V4, przejęta $\mathrm{w}$ lipcu $2020 \mathrm{r}$. i przypadająca w czasie tego przewodnictwa trzydziesta rocznica podpisania Deklaracji Wyszehradzkiej (luty 2021 r.), stwarzają szasnę, że czeskie i słowackie oczekiwania, aby podkreślać ich rolę $\mathrm{w}$ regionie, zostaną spełnione.

Inicjatywa Trójmorza była projektem autorskim, który powstał z woli kilku przywódców środkowoeuropejskich. Choć można w tych działaniach dostrzec inspirację zewnętrzną (amerykańską), to jednak nie to przesądziło, że projekt rozwija się mimo licznych barier, ale umiejętność autonomicznego działania i definiowania możliwych do osiągnięcia celów. Inicjatywa Trójmorza przez Pragę i Bratysławę zostałaby najchętniej, w najbardziej 
optymalnym scenariuszu, ograniczona do szeroko wykorzystywanego formatu v4+. Pozwoliłoby to poszczególnym państwom wyszehradzkim zachować pełną kontrolę nad całym procesem współpracy regionalnej, na co wskazywała wspomniana już analiza Víta Dostála. Ustalenie listy wspólnych projektów infrastrukturalnych oraz uruchomienie funkcjonowania Funduszu Trójmorza otworzyło perspektywę pragmatycznego podejścia do całej inicjatywy i wykorzystanie tego instrumentu do uzyskania dodatkowych środków finansowanych na ważne dla tych państw inwestycje.

\section{Załącznik}

Tabela 1. Szefowie delegacji z państw V4 na szczytach Inicjatywy Trójmorza

\begin{tabular}{|c|c|c|c|c|}
\hline Szczyt & Polska & Czechy & Słowacja & Węgry \\
\hline $\begin{array}{l}\text { 25-26 VIII } 2016 \\
\text { Chorwacja } \\
\text { (Dubrownik) }\end{array}$ & $\begin{array}{l}\text { Andrzej Duda- } \\
\text { prezydent RP }\end{array}$ & $\begin{array}{l}\text { Dan Ťok- } \\
\text { minister transportu }\end{array}$ & $\begin{array}{l}\text { Peter Pellegrini- } \\
\text { wicepremier } \\
\text { ds. inwestycji } \\
\text { i informatyzacji }\end{array}$ & $\begin{array}{l}\text { János Áder-prezydent } \\
\text { Węgier }\end{array}$ \\
\hline $\begin{array}{l}\text { 6-7 VII } \\
\text { 2017 Polska } \\
\text { (Warszawa) }\end{array}$ & $\begin{array}{l}\text { Andrzej Duda- } \\
\text { prezydent RP }\end{array}$ & $\begin{array}{l}\text { Jan Hamáček - } \\
\text { przewodniczący } \\
\text { (marszałek) Izby } \\
\text { Poselskiej Parlamentu } \\
\text { Republiki Czeskiej }\end{array}$ & $\begin{array}{l}\text { Andrej Kiska- } \\
\text { prezydent Republiki } \\
\text { Słowackiej }\end{array}$ & $\begin{array}{l}\text { János Áder - prezydent } \\
\text { Węgier }\end{array}$ \\
\hline $\begin{array}{l}\text { 17-19 IX } 2018 \\
\text { Rumunia } \\
\text { (Bukareszt) }\end{array}$ & $\begin{array}{l}\text { Andrzej Duda- } \\
\text { prezydent RP }\end{array}$ & $\begin{array}{l}\text { Radek Vondráček - } \\
\text { przewodniczący } \\
\text { (marszałek) Izby } \\
\text { Poselskiej Parlamentu } \\
\text { Republiki Czeskiej }\end{array}$ & $\begin{array}{l}\text { Andrej Kiska- } \\
\text { prezydent Republiki } \\
\text { Słowackiej }\end{array}$ & $\begin{array}{l}\text { János Áder-prezydent } \\
\text { Węgier zapowiadany } \\
\text { (ostatecznie nie } \\
\text { dojechał, jego samolot } \\
\text { uległ awarii) }\end{array}$ \\
\hline $\begin{array}{l}5-7 \text { VI } 2019 \\
\text { Słowenia } \\
\text { (Lublana) }\end{array}$ & $\begin{array}{l}\text { Andrzej Duda- } \\
\text { prezydent RP }\end{array}$ & $\begin{array}{l}\text { Miloš Zeman - } \\
\text { prezydent Republiki } \\
\text { Czeskiej }\end{array}$ & $\begin{array}{l}\text { Zuzana Čaputová - } \\
\text { prezydent Republiki } \\
\text { Słowackiej }\end{array}$ & $\begin{array}{l}\text { Péter Szijjártó - } \\
\text { minister spraw } \\
\text { zagranicznych Węgier }\end{array}$ \\
\hline
\end{tabular}

Źródło: opracowanie własne, na podstawie P. Kowal, A. Orzelska-Stączek, Inicjatywa Trójmorza..., S. 63-65 oraz The Three Seas, [dostęp: 30 VI 2020], dostępny w internecie: <https://www.three.si/>.

\section{Bibliografia}

Bajda P., Małe państwo europejskie na arenie międzynarodowej. Polityka zagraniczna Republiki Słowackiej w latach 1992-2016, Ośrodek Myśli Politycznej i Wydawnictwo Naukowe Uniwersytetu Kardynała Stefana Wyszyńskiego w Warszawie, Kraków-Warszawa 2018.

Bajda P., Wspótpraca wyszehradzka - nowe wyzwania w zmieniającej się Europie. Ocena polskiej prezydencji $w$ V4 2012/13. Od minilateralizmu do makroregionu, [w:] Europa Środkowa - Central Europe, t. 3: Instytucje demokracji bezpośredniej, zagadnienia systemów politycznych $i$ współpracy regionalnej w Europie Środkowej, red. K. Koźbiał, Państwowa Wyższa Szkoła Zawodowa im. Rotmistrza Pileckiego w Oświęcimiu, Oświęcim 2015. 
Bajda P., The Visegrad Group in the security architecture of Europe, „The Warsaw Institute Review" 2018, vol. 4, No. 7, s. 10-17 [online], dostępny w internecie [dostęp: 24 VI 2020]: <https://warsawinstitute.review/category/issue-2018/ issue-42018/>.

Dostál V., Understanding New Polish Intermarium: Trap or Triumph for the Visegrad Group?, „Policy Paper” 2016, vol. 3, s. 2-8 [online], dostępny w internecie [dostęp: 24 VI 2020]: <http://www.amo.cz/wp-content/uploads/2016/o6/amocz _ PP_03_2016_web.pdf $>$.

Groszkowski J., Deklaracja sławkowska. Nowy format wspótpracy regionalnej, Ośrodek Studiów Wschodnich [online], 4 II 2015 [dostęp: 13 VI 2020], dostępny w internecie: <https://www.osw.waw.pl/pl/publikacje/analizy/2015-02-04/deklaracja-slawkowskanowy-format-wspolpracy-regionalnej $>$.

Haszczyński J., Milos Zeman - Donald Trump. Czeski film z niewdzięcznym prezydentem USA, „Rzeczpospolita” [online], 27 VII 2017 [dostęp: 25 VI 2020], dostępny w internecie: <https://www.rp.pl/Swiat/307249892-Milos-Zeman---DonaldTrump-Czeski-film-z-niewdziecznym-prezydentem-USA.html $>$.

Janulewicz Ł., Żornaczuk T., Niemcy wobec Inicjatywy Trójmorza, „Biuletyn Polski Instytut Spraw Międzynarodowych" 2019, nr 120 (1868).

Kowal P., Orzelska-Stączek A., Inicjatywa Trójmorza: geneza, cele i funkcjonowanie, Instytut Studiów Politycznych PAN, Warszawa 2019.

Masaryk T. G., Kroméríž lectures. Problem of a small nation, Nakladatelství TRIGON, Praha 2010.

Naím M., Minilateralism. The magic number to get real international action, „Foreign policy" [online], 21 VI 2006 [dostęp: 16 VI 2020], dostępny w internecie: <https:// foreignpolicy.com/2009/06/21/minilateralism/>.

Orzelska-Stączek A., Ukielski P., Inicjatywa Trójmorza z perspektywy jej uczestników, Instytut Studiów Politycznych PAN, Warszawa 2020.

Priority Interconnections Projects, dostępny w internecie [dostęp: 29 VI 2020]: <http://three-seas.eu/wp-content/uploads/2018/o9/LIST-OF-PRIORITY-INTERCONNECTION-PROJECTS-2018.pdf $>$.

Żarna K., Od Mečiara do Dzurindy. Główne kierunki polityki zagranicznej Republiki Słowackiej w latach 1993-2002, Wydawnictwo Uniwersytetu Rzeszowskiego, Rzeszów 2015. 